\title{
8-Alkylthio-6-thio-substituted Theophylline Analogues as Selective Progesterone Receptor Antagonists
}

\author{
Irene O. Aninye ${ }^{\dagger}, K^{2}$ neth C. Berg ${ }^{\ddagger}$, Andy R. Mollo $\ddagger$, Steven K. Nordeen§, Elizabeth M. \\ Wilson" , and David J. Shapiro $\neq$, , \\ †Department of Molecular and Integrative Physiology, University of Illinois at Urbana-Champaign, \\ Urbana, IL 61801 \\ FDepartment of Biochemistry, University of Illinois at Urbana-Champaign, Urbana, IL 61801 \\ $\S$ Department of Pathology, University of Colorado Anschutz Medical Campus, Aurora, CO 80045 \\ "Department of Pediatrics, and Biochemistry and Biophysics, University of North Carolina School \\ of Medicine, Chapel Hill, NC 27599
}

\begin{abstract}
The progesterone receptor (PR) plays a key role in reproduction and is important in cancers of the reproductive tract. Current PR antagonists usually compete for progestin binding in the PR ligandbinding pocket and often exhibit cross-binding with other members of the steroid receptor family. Using stably transfected cells expressing reporter genes, a set of $\sim 150$ theophylline analogues were screened for their ability to inhibit progesterone, estrogen, glucocorticoid and androgen signaling. The structure-activity studies presented here identify branched 8-alkylthio-6-thio-substitutions of theophylline as selective PR inhibitors. 6-thio-8-(2-ethylbutyl)thiotheophylline (51), the most extensively studied derivative, does not act by competing with progestins for binding in the ligand-binding pocket of PR. It demonstrated the ability to inhibit the mouse mammary tumor virus (MMTV)-luciferase reporter and endogenous PR-regulated alkaline phosphatase activity in T47D breast cancer cells. Compound $\mathbf{5 1}$ is the lead member of a novel class of PR inhibitors that act outside the PR ligand-binding pocket, thus serving as a novel probe to investigate PR action and a lead for further development.
\end{abstract}

\section{Keywords}

Progesterone receptor; Steroid receptor; Small molecule inhibitor; Theophylline analogue; Structure activity relationship

\section{Introduction}

Progesterone plays a key role in regulating ovulation, uterine contractility, and mammary tissue morphogenesis [1,2]. Most biological actions of progestins result from the activation of the progesterone receptor (PR), a ligand-dependent transcription factor [3]. Hormone

\footnotetext{
(C) 2012 Elsevier Inc. All rights reserved.

*Address all correspondence and requests to: David J. Shapiro, Department of Biochemistry, University of Illinois, 600 S. Mathews Ave., Urbana IL 61801. Phone: 217-333-1788; Fax: 217-244-5858; djshapir@illinois.edu.

Publisher's Disclaimer: This is a PDF file of an unedited manuscript that has been accepted for publication. As a service to our customers we are providing this early version of the manuscript. The manuscript will undergo copyediting, typesetting, and review of the resulting proof before it is published in its final citable form. Please note that during the production process errors may be discovered which could affect the content, and all legal disclaimers that apply to the journal pertain.
} 
binding in the PR ligand-binding domain (LBD) induces a conformation that releases the heat shock protein complex, enabling PR to more efficiently enter the nucleus and bind as a homodimer to DNA response elements and regulate the transcription of target genes [4].

Depending on the tissue, estrogens and progestins can work synergistically or antagonistically. While estrogen increases the levels of the two PR isoforms, PR-A and PR$B$, progestins binding to PR can suppress estradiol-stimulated estrogen receptor a (ERa) activity [5]. PR antagonists have been developed as potential treatment options for progesterone-dependent gynecological disorders, such as endometriosis and uterine and breast cancers. In addition to their ability to inhibit the effects of endogenous progesterone, PR antagonists repress estrogen-dependent proliferation of the mammary gland and uterus [6,7]. Most antiprogestins, like mifepristone (RU486), are steroidal compounds that compete with progestins binding in the ligand-binding pocket of PR. Classical PR antagonists bind with high affinity and exhibit nanomolar potency, however, they often exhibit significant binding to the glucocorticoid receptor (GR) $[8,9]$.

In a high-throughput screen, our laboratory identified a small molecule inhibitor of steroid receptor transactivation [10], 8-benzylsulfanylmethyl-1,3-dimethyl-3,7-dihydro-purine-2,6dione (TPBM), that belongs to a family of theophylline derivatives originally synthesized by Dietz \& Burgison [11,12]. A second small molecule characterized from this set, 8-((4-(4fluorophenyl)-4-oxobutyl)thio)-1,3-dimethyl-6-thioxo-6,7-dihydro- $1 H$-purin-2(3H)-one (TPSF), showed increased potency and a different mode of action than TPBM [13]. While TPBM acts in part by blocking receptor binding to response element DNA, TPSF increases the degradation of ligand-bound ERa. These compounds demonstrate the diversity of action and specificity that this set of analogues present in modulating steroid receptor action. Structure activity relationship (SAR) studies identify correlations between changes in biological activity and molecular structure of a set of similar compounds.

In the course of our SAR studies, we gained the unusual capacity to evaluate the activity of small molecules as inhibitors of transactivation mediated by 4 major steroid hormone receptors: ER, PR, GR, and androgen receptor (AR). In our evaluation of this set of structurally related theophylline derivatives, we identified 8-alkylthio-6-thiotheophyllines that inhibited PR-mediated transactivation better than the parent compound. A subset of small molecules, having saturated carbon-chain branching, exhibited a clear preference for inhibiting PR relative to the other steroid receptors. Here, we describe a novel structural motif that exhibits receptor specificity and describe a small molecule inhibitor of PR that does not act by competing with progestins for binding to PR.

\section{Experimental}

\subsection{Chemistry}

2.1.1. General-Theophylline (1) was obtained from Sigma (St. Louis, MO). Compounds 2-55 were synthesized as described by Dietz and Burgison [11,12], and obtained from the NCI Developmental Therapeutics Program. Solid compounds were dissolved in dimethyl sulfoxide (DMSO) and stored at $-20^{\circ} \mathrm{C}$. The lead compound, 6-thio-8-(2ethylbutyl)thiotheophylline (51), has $85 \%$ chemical purity as determined by LC/MS.

\subsection{Biology}

2.2.1. Cell Culture-Unless otherwise indicated, cells were maintained at $37^{\circ} \mathrm{C}$ in $5 \%$ $\mathrm{CO}_{2}$ in phenol red-free medium containing $1 \%$ penicillin/streptomycin and $10 \%$ fetal bovine serum (FBS) (Atlanta Biological, Atlanta, GA). T47D/A1-2 breast cancer cells, stably transfected to express additional GR and a mouse mammary tumor virus (MMTV)- 
luciferase reporter [14], were maintained in minimum essential medium (MEM) supplemented with $10 \mathrm{mM}$ HEPES, pH 7.4, $2 \mathrm{mM}$ L-glutamine, and $0.2 \mathrm{mg} / \mathrm{ml}$ Geneticin (G418). T47D-KBluc cells stably expressing an (ERE) 3 -luciferase reporter [15] were maintained in RPMI 1640 supplemented with $10 \mathrm{mM}$ HEPES, pH 7.5, $2 \mathrm{mM}$ 1-glutamine, $1.5 \mathrm{~g} / \mathrm{l}$ sodium bicarbonate, $4.5 \mathrm{~g} / \mathrm{l}$ glucose, and $1 \mathrm{mM}$ sodium pyruvate. HeLa-AR1C-PSALuc-A6 cells stably expressing AR and a prostate-specific antigen (PSA)-luciferase reporter [13] were maintained in MEM supplemented with $2 \mathrm{mM}$ L-glutamine, $1 \mathrm{mM}$ sodium pyruvate, $0.1 \mathrm{mg} / \mathrm{ml}$ hygromycin B (Roche Applied Science), and $0.5 \mathrm{mg} / \mathrm{ml} \mathrm{G} 418$. T47D cells were maintained in phenol red MEM supplemented with $10 \mathrm{mM}$ HEPES, pH 7.4, and 2 $\mathrm{mM}$ glutamine. MCF-7 breast cancer cells were maintained in MEM supplemented with 10 $\mathrm{mM}$ HEPES, pH 7.4, $2 \mathrm{mM}$ glutamine, and 5\% FBS. Four days before experiments, cells were transferred to the phenol red-free media described above, containing $10 \%$ dextrancharcoal treated (CD)-CS (T47D/A1-2 and HeLa cells) or 10\% CD-FBS (T47D-KBluc and T47D cells) with hormone or compound added in DMSO. MCF-7 cells were transferred to $5 \%$ CD-FBS and assays were conducted in 10\% CD-CS media.

2.2.2. Reporter Gene Assays-Assays for progesterone and glucocorticoid-dependent transactivation were performed in T47D/A1-2 breast cancer cells. Estrogen and androgendependent transactivations were assayed in T47D-KBluc and HeLa-A6 cells, respectively. Cells were seeded overnight and then treated with $5 \mathrm{nM}$ of progesterone $(\mathrm{P})$, dexamethasone (DEX), estradiol $\left(\mathrm{E}_{2}\right)$, dihydrotestosterone (DHT), or ethanol vehicle - with or without 10 $\mu \mathrm{M}$ of the test compounds in DMSO. After $24 \mathrm{~h}$, cells were washed once with phosphate buffered saline (PBS) and lysed in passive lysis buffer (Promega, Madison WI). Luciferase activity was determined using BrightGlo firefly luciferase reagent from Promega.

2.2.3. Alkaline Phosphatase Assay-T47D cells were seeded overnight and then treated for $24 \mathrm{~h}$ with $2.5 \mathrm{nM}$ P, with or without test compounds in DMSO. Cells were washed once with PBS, lysed in harvest buffer $(20 \mathrm{mM}$ potassium phosphate, $\mathrm{pH} 7.8,5 \mathrm{mM}$ $\mathrm{MgCl}_{2}, 0.5 \%$ Triton X-100) and frozen at $-70^{\circ} \mathrm{C} .5 \mu \mathrm{l}$ of thawed supernatant was removed and assayed in a 96-well plate in $25 \mu \mathrm{l}$ of assay buffer containing $100 \mathrm{mM}$ diethanolamine, $\mathrm{pH} 9.5,1 \mathrm{mM} \mathrm{MgCl} 2,0.4 \mathrm{mM}$ CSPD substrate (Applied Biosystems/Tropix) and $1 \mathrm{X}$ Emerald II enhancer (Applied Biosystems/Tropix). After $1 \mathrm{~h}$ at room temperature, luminescence was measured in the visible spectrum (emission max. $542 \mathrm{~nm}$ ).

2.2.4. Enzyme Inhibition Assays-Assays using purified luciferase protein and the test compounds were performed to rule out direct effects on luciferase enzyme activity. $0.05 \mathrm{ng}$ of purified luciferase protein was added to $5 \mu \mathrm{l}$ OneGlo Buffer (Promega) in a 96 well plate at a final concentration of $0.01 \mathrm{ng} / \mu 1$ luciferase protein. Each compound was diluted to 10 $\mu \mathrm{M}$ in buffer. $5 \mu \mathrm{l}$ BrightGlo firefly luciferase reagent was added and incubated for 5 minutes before measuring luciferase activity. To test whether compounds directly affected alkaline phosphatase (AlkP) activity, lysates from cells treated with $2.5 \mathrm{nM}$ P, to induce sufficient AlkP, were aliquoted and treated with $10 \mu \mathrm{M}$ of each compound for 15 minutes. Assay buffer (described above) was added to the lysate, incubated at room temperature for 1 $\mathrm{h}$, and luminescence was measured.

2.2.5. RNA Isolation and Quantitative PCR-To induce alkaline phosphatase expression, cells were maintained in medium containing $10 \mathrm{nM} \mathrm{P}$ and the indicated concentrations of each compound in DMSO for $24 \mathrm{~h}$. Total RNA was isolated using the RNeasy Mini Kit (QIAGEN, Austin, TX) and $1 \mu \mathrm{g}$ of RNA was reverse transcribed using ProtoScript M-MuLV First Strand cDNA Synthesis Kit (New England BioLabs, Ipswich, MA). Quantitative PCR was performed using Power SYBR Green PCR Master Mix (Applied Biosystems, United Kingdom). mRNA levels were measured by quantitative RT- 
PCR as described [13]. Primers used in qRT-PCR were: AlkP, forward ( $5^{\prime}-$

TCGCCTACCAGCTCATGCATAACA) and reverse ( $5^{\prime}$ -

TGAAGCTCTTCCAGGTGTCAACGA); and 36B4 internal standard, forward ( $5^{\prime}$ GTGTTCGACAATGGCACAT) and reverse (5'-GACACCCTCCAGGAAGCGA).

2.2.6. Receptor Binding Assay-Relative binding affinities were determined in a competitive radiometric assay as previously described [16-18] using $10 \mathrm{nM}$ tritiated tracer, unlabeled promegestone (R5020) as standard, and $10 \mathrm{nM}$ purified full length recombinant human PR-B (Pan Vera/Invitrogen, Carlsbad, CA). Incubations were for $18-24 \mathrm{~h}$ at $0^{\circ} \mathrm{C}$. Hydroxyapatite (BioRad, Hercules, CA) was used to absorb receptor-ligand complexes, and free ligand was removed by washing with cold buffer. The data were analyzed using Prism 4.0. Binding affinities are expressed as relative binding affinity values with unlabeled R5020 set to $100 \%$. The ${ }^{3} \mathrm{H}$ tracer, [17a-methyl- $\left.{ }^{3} \mathrm{H}\right]-\mathrm{R} 5020$ (Perkin-Elmer, Boston, MA), binds PR with a $\mathrm{K}_{\mathrm{d}}$ of $0.4 \mathrm{nM}$.

2.2.7. Statistical Analysis-Results are expressed as mean \pm standard error (SEM) of at least three independent experiments. Student's t-test was used for comparison of the means between two groups. Significance was established when $p<0.05$.

\section{Results}

The ability of 8-thioalkyltheophyllines to inhibit the activity of PR, ERa, GR and AR was assessed using stably transfected cell lines, each expressing receptor-specific hormone response elements linked to a luciferase reporter. PR and GR activities were assayed in T47D/A1-2 breast cancer cells stably transfected to express a mammary tumor virus (MMTV)-luciferase promoter. ERa activity was assayed in T47D-KBluc cells expressing a reporter that contains 3 copies of the consensus estrogen response element (ERE) $3^{-}$ luciferase. AR activity was assayed in HeLa-A6 cells stably transfected to express AR and a prostate specific antigen (PSA)-luciferase reporter. Compounds were prepared as $10 \mathrm{mM}$ stocks in DMSO and tested at $10 \mu \mathrm{M}$. The final DMSO concentration $(0.1 \%)$ was below the $0.3 \%(\mathrm{v} / \mathrm{v})$ concentration associated with cytotoxic effects [10]. Receptor activity was assayed in the presence of progesterone $(\mathrm{P})$ for $\mathrm{PR}, 17 \beta$-estradiol $\left(\mathrm{E}_{2}\right)$ for $\mathrm{ER}$, dexamethasone (DEX) for GR, and dihydrotestosterone (DHT) for AR. Table 1 summarizes the percent transcriptional activity remaining in the presence of theophylline and 54 of its structural derivatives. A table containing similar data for 93 more structurally diverse analogues is provided in the Appendix.

Unmodified theophylline did not inhibit transactivation by any of the steroid receptors, whereas several theophylline derivatives exhibited varying levels of inhibition. To increase lipid solubility, oxygens in the $\mathrm{X}$ and $\mathrm{Y}$ positions were substituted with sulfurs. The resulting 8-alkylthio-2-thio, 8-alkylthio-6-thio, and 8-alkylthio-2,6-dithiotheophyllines displayed increased inhibition of transactivation, with 6-thio-substituted theophyllines being the most potent inhibitors. For example, compounds $\mathbf{2 4}$ and $\mathbf{3 1}$ reduced steroid receptor activity to a greater extent than their unsubstituted, 2-thio and 2,6-dithio counterparts (23-26 and 30-33, respectively).

The 6-thiotheophyllines with 8-alkylthio-substitutions 5-9 carbons in length $(\mathbf{2 4}, \mathbf{3 1}$, and $\mathbf{3 4})$ inhibited PR activity 41-58\%, but lacked specificity. Efficacy and specificity for PR was improved with compounds with alkyl branching. For example, 45 and 46, with a single branched methyl group were moderately potent inhibitors of PR with no activity against ER, GR, and AR. Methyl branching on the terminal carbon improved efficacy, but also inhibited $\mathrm{ER}$, as in the case of $\mathbf{4 8}$ and $\mathbf{4 9}$. Increasing the number of methyl groups with compound $49^{\prime}$ s tertiary substitution inhibited PR activity 44\%, but it also inhibited ER and GR. 
Compounds 51 and $\mathbf{5 2}$ had ethyl group side chains and inhibited PR to a greater extent than compounds with methyl side chains. The location of the ethyl side chain was also slightly more favorable in $\mathbf{5 1}$ and $\mathbf{5 2}$ which contain terminal branching.

Based on the results of the primary screen that indicated $\mathrm{IC}_{50} \mathrm{~s}<10 \mu \mathrm{M}$ and specificity for PR, the alkyl-branched 8-alkylthio-6-thiotheophylline, compound 51, was selected as the lead compound for further study. Its structure is shown in Figure 1A.

Since most current PR antagonists also inhibit GR, we assessed the potency and specificity of compound $\mathbf{5 1}$ in dose-response studies that compared its ability to inhibit PR, ER, GR, and AR (Figure 1B). In the luciferase reporter assays, $\mathbf{5 1}$ preferentially inhibited PR, followed by ER, AR, and then GR. Its IC I0 $_{50}$ was $2.3 \mu \mathrm{M}$ for PR, which was 2 to 6 fold lower than for the other receptors (Figure 1C). Since PR and GR activities were assessed in a single line of T47D cells, using the same MMTV-luciferase reporter, the absence of GR inhibition is not an artifact due to use of different cells and promoters. In these cells, compound 51 was a 6.1-fold more potent inhibitor of PR than GR, and compounds 48 and 52, which also contain this novel branched-chain alkyl motif, showed up to 10-fold increased potency on PR than GR (Figure A.1).

We next tested the ability of the lead compound to inhibit progesterone induction of the endogenous alkaline phosphatase (AlkP) gene in T47D human breast cancer cells $[19,20]$. In these cells, AlkP enzyme activity was induced 23 fold by progesterone, but not by $\mathrm{E}_{2}$, DEX, or DHT (data not shown). $\mathbf{5 1}$ potently inhibited progesterone induction of AlkP activity with an $\mathrm{IC}_{50}$ of $1.2 \mu \mathrm{M}$ and complete inhibition by $5 \mu \mathrm{M}$ (Figure $2 \mathrm{~A}$ ).

We tested the possibility that the inhibition by $\mathbf{5 1}$ was an artifact due to direct inhibition of luciferase or alkaline phosphatase enzyme activity. Compound $\mathbf{5 1}$ did not inhibit the enzymatic activity of $0.05 \mathrm{ng}$ of pure luciferase protein $(\mathrm{t}>0.1)$. In lysates from cells in which progesterone was used to induce alkaline phosphatase activity ( $16.5 \pm 0.3$ fold induction relative to control), treatment with $\mathbf{5 1}$ failed to significantly inhibit activity ( $\mathrm{t}$ > 0.3) (data not shown).

The specificity study in Fig. 1 used stably transfected reporter genes. To evaluate the effects of $\mathbf{5 1}$ on the expression of an endogenous gene, we used qRT-PCR to investigate progesterone induction of alkaline phosphatase mRNA. The $11.8 \pm 1.6$ fold induction in mRNA levels was inhibited $74 \%$ by $5 \mu \mathrm{M}$ of compound $\mathbf{5 1}$, and completely blocked at 10 $\mu \mathrm{M}$ (Figure 2B).

To compare 51's ability to inhibit an ER-regulated endogenous gene, we analyzed pS2 mRNA. We tested the effect of compound $\mathbf{5 1}$ on ER at an early time, at which estrogen-ER has not yet induced PR, thus the cells were maintained in medium containing $5 \mu \mathrm{M}$ compound $\mathbf{5 1}$ for only 2 hours. Under the same conditions in which $\mathbf{5 1}$ completely blocked the progesterone induction of AlkP mRNA, it had no effect on the $17 \beta$-estradiol induction of pS2 mRNA (Figure A.2). As a positive control, the estrogen antagonist, ICI 182,780 inhibited induction of pS2 mRNA. This data provides additional evidence that compound $\mathbf{5 1}$ preferentially inhibits PR-mediated gene expression.

Most PR antagonists compete with progesterone for binding in the ligand-binding domain of the receptor. At functionally significant concentrations, compound $\mathbf{5 1}$ had little or no ability to compete with the radio-labeled synthetic progestin, promegestone (R5020), for binding to PR (Figure 3) and bound 4,700 fold less well than R5020. These results indicate that $\mathbf{5 1}$ is unlikely to act by competing with progestins for binding in $\mathrm{PR}^{\prime} \mathrm{s}$ ligand-binding pocket. It 
remains possible that binding of $\mathbf{5 1}$, and other thiotheophylline derivatives, to a second site on PR triggers a conformational change that influences the ability of PR to bind progestins.

\section{Discussion}

Previous studies showed that a set of 8-alkylthiotheophyllines displayed very weak antitumor activity [11]. During a screen of a diversity test library, one of these compounds was identified as an inhibitor of ERa action [10]. This set of small molecules was further explored to identify a structural motif that confers preferential inhibition of steroid hormone receptor activity. Replacing the oxygens in theophylline with sulfurs increased general inhibition of steroid receptor activity. 6-thio substitutions were more effective than 2-thio or 2,6-dithio substitutions. 8-thioalkyl substitution further increased potency, with preferential inhibition of PR as saturated chains 5-9 carbons in length were included. At shorter chain lengths, inhibition was generally weak, while longer chain lengths were not specific for inhibition of PR. Addition of saturated carbon-chain branching increased selectivity and potency for inhibiting PR activity. Our SAR investigation of PR, ER, GR, and ARresponsive reporter genes identified compound $\mathbf{5 1}$, which belongs to a set of saturated branched 8-alkylthio-6-thio-substituted theophyllines that preferentially inhibited PR. Compound 51 demonstrated pure antagonist effects - at concentrations of $30 \mu \mathrm{M}$ and higher, there was no observed agonist activity or decrease in antagonism as is often seen with many selective PR modulators like RU486.

The LBDs of steroid receptors share a similar structure with a moderately conserved amino acid sequence. Therefore, PR antagonists, like RU486 that binds in the ligand-binding pocket, tend to discriminate poorly between receptors. Their ability to exert antiglucocorticoid activity limits the use of many PR antagonists. Our ability to identify small molecules that selectively inhibit PR over GR activity was enhanced by testing them on the same MMTV-luciferase reporter in T47D cells. Since the small molecules were assayed for inhibition of PR and GR on the same promoter in the same cells, it is highly unlikely that general toxicity is responsible for selective inhibition of PR by compound $\mathbf{5 1}$.

Ligand competition studies were used to evaluate the ability of $\mathbf{5 1}$ to compete with a progestin for binding to the ligand-binding pocket of PR. Based on these studies, compound 51 and other branched 8-alkylthio-6-thio-substitutions likely exert their actions outside the progestin binding pocket.

Compound 51 inhibited PR-induced enzyme activity of the stably transfected luciferase reporter and endogenous alkaline phosphatase. Using quantitative RT-PCR, we also showed that $\mathbf{5 1}$ inhibits the progesterone-PR induction of AlkP mRNA. Thus, compound $\mathbf{5 1}$ is a noncompetitive inhibitor of PR-mediated gene expression.

PR, GR and AR are a subgroup of steroid receptors that can bind to the same DNA response element. How target genes are selectively activated by individual receptors is not well understood. Compound $\mathbf{5 1}$ may prove useful in elucidating differential effects of PR, GR and AR on gene expression and in distinguishing actions mediated by PR from those mediated by GR and other closely related members of the steroid receptor family.

\section{Supplementary Material}

Refer to Web version on PubMed Central for supplementary material. 


\section{Acknowledgments}

We thank Ms. Kathryn Carlson and Prof. John Katzenellenbogen (University of Illinois) for conducting the radioligand competition assays.

\section{Appendix A. Supplementary Data}

A table reporting the inhibition of steroid receptor action for the remaining 93 analogues of theophylline and the dose response curves of $\mathbf{4 8}$ and $\mathbf{5 2}$, compounds closely related to lead compound $\mathbf{5 1}$. This material is available via the internet at http://www.journals.elsevier.com/steroids/.

\section{Abbreviations}

$\begin{array}{ll}\text { AlkP } & \text { alkaline phosphatase } \\ \text { AR } & \text { androgen receptor } \\ \text { ER } & \text { estrogen receptor } \\ \text { GR } & \text { glucocorticoid receptor } \\ \text { LBD } & \text { ligand binding domain } \\ \text { PR } & \text { progesterone receptor } \\ \text { SAR } & \text { structure activity relationship }\end{array}$

\section{References}

[1]. Mukherjee A, Amato P, Allred DC, Fernandez-Valdivia R, Nguyen J, O’Malley BW, et al. Steroid receptor coactivator 2 is essential for progesterone-dependent uterine function and mammary morphogenesis: insights from the mouse--implications for the human. J Steroid Biochem Mol Biol. 2006; 102:22-31. [PubMed: 17045797]

[2]. onneely OM, Mulac-Jericevic B, DeMayo F, Lydon JP, O’Malley BW. Reproductive functions of progesterone receptors. Recent Progr Horm Res. 2002; 57:339-55. [PubMed: 12017551]

[3]. Griekspoor A, Zwart W, Neefjes J, Michalides R. Visualizing the action of steroid hormone receptors in living cells. Nucl Recept Signal. 2007; 5:e003. [PubMed: 17464358]

[4]. Allan GF, Leng X, Tsai SY, Weigel NL, Edwards DP, Tsai MJ, et al. Hormone and antihormone induce distinct conformational changes which are central to steroid receptor activation. J Biol Chem. 1992; 267:19513-20. [PubMed: 1326555]

[5]. Szabo M, Kilen SM, Nho SJ, Schwartz NB. Progesterone receptor A and B messenger ribonucleic acid levels in the anterior pituitary of rats are regulated by estrogen. Biol Reprod. 2000; 62:95102. [PubMed: 10611072]

[6]. Wilkens J, Williams ARW, Chwalisz K, Han C, Cameron IT, Critchley HOD. Effect of asoprisnil on uterine proliferation markers and endometrial expression of the tumour suppressor gene, PTEN. Human Reprod. 2009; 24:1036-44.

[7]. shi YE, Liu YE, Lippman ME, Dickson RB. Progestins and antiprogestins in mammary tumour growth and metastasis. Human Reprod. 1994; 9(Suppl 1):162-73.

[8]. Leonhardt SA, Edwards DP. Mechanism of action of progesterone antagonists. Exp Biol Med (Maywood). 2002; 227:969-80. [PubMed: 12486206]

[9]. Chwalisz K, Perez MC, Demanno D, Winkel C, Schubert G, Elger W. Selective progesterone receptor modulator development and use in the treatment of leiomyomata and endometriosis. Endocr Rev. 2005; 26:423-38. [PubMed: 15857972]

[10]. Mao C, Patterson NM, Cherian MT, Aninye IO, Zhang C, Montoya JB, et al. A new small molecule inhibitor of estrogen receptor alpha binding to estrogen response elements blocks 
estrogen-dependent growth of cancer cells. J Biol Chem. 2008; 283:12819-30. [PubMed: 18337247]

[11]. Dietz AJ, Burgison RM. The Synthesis and Pharmacologic Evaluation of a Series of 8-AlkylthioThiated Theophyllines. J Med Chem. 1966; 9:500-6. [PubMed: 5968014]

[12]. Dietz AJ, Burgison RM. The Synthesis of Some 8-Alkylthio-2-thiotheophyllines and 8Alkylthio-6-thiotheophyllines. J Med Chem. 1965; 9:160. [PubMed: 5958948]

[13]. Kretzer NM, Cherian MT, Mao C, Aninye IO, Reynolds PD, Schiff R, et al. A noncompetitive small molecule inhibitor of estrogen-regulated gene expression and breast cancer cell growth that enhances proteasome-dependent degradation of estrogen receptor \{alpha\}. J Biol Chem. 2010; 285:41863-73. [PubMed: 21041310]

[14]. Nordeen SK, Kuhnel B, Lawler-Heavner J, Barber DA, Edwards DP. A quantitative comparison of dual control of a hormone response element by progestins and glucocorticoids in the same cell line. J Mol Endocrinol. 1989; 3:1270-8.

[15]. Wilson VS, Bobseine K, Gray LE. Development and characterization of a cell line that stably expresses an estrogen-responsive luciferase reporter for the detection of estrogen receptor agonist and antagonists. Toxicol Sci. 2004; 81:69-77. [PubMed: 15166400]

[16]. Carlson KE, Choi I, Gee A, Katzenellenbogen BS, Katzenellenbogen JA. Altered ligand binding properties and enhanced stability of a constitutively active estrogen receptor: evidence that an open pocket conformation is required for ligand interaction. Biochemistry. 1997; 36:14897-905. [PubMed: 9398213]

[17]. Brandes SJ, Katzenellenbogen JA. Fluorinated androgens and progestins: molecular probes for androgen and progesterone receptors with potential use in positron emission tomography. Mol Pharmacol. 1987; 32:391-403. [PubMed: 3499564]

[18]. Katzenellenbogen JA, Johnson HJ, Myers HN. Photoaffinity labels for estrogen binding proteins of rat uterus. Biochemistry. 1973; 12:4085-92. [PubMed: 4745660]

[19]. Di Lorenzo D, Gianna M, Savoldi GF, Ferrar F, Albertini A, Garattini E. Progesterone Induced Expression of Alkaline Phosphatase Is Associated with a Secretory Phenotype in T47D Breast Cancer Cells. Biochem Biophys Res Comm. 1993; 192:1066-72. [PubMed: 8507182]

[20]. Fernley HN, Walker PG. Studies on alkaline phosphatase. Inhibition by phosphate derivatives and the substrate specificity. Biochem J. 1967; 104:1011-8. [PubMed: 4292874] 


\section{Highlights}

$>\quad$ SAR of theophylline analogues against 4 major steroid receptors

$>\quad$ Novel motif preferentially inhibits progesterone receptor activity

$>$ Inhibitor is pure antagonist of PR-mediated reporter and endogenous gene activity

$>\quad$ Compound 51 does not display the properties of a competitive ligand 
(A)

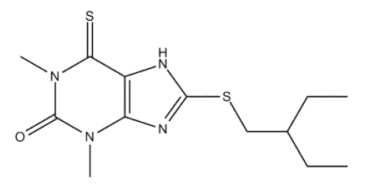

(C)

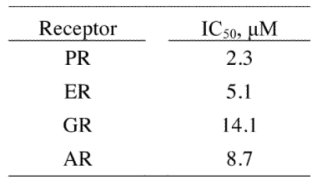

(B)

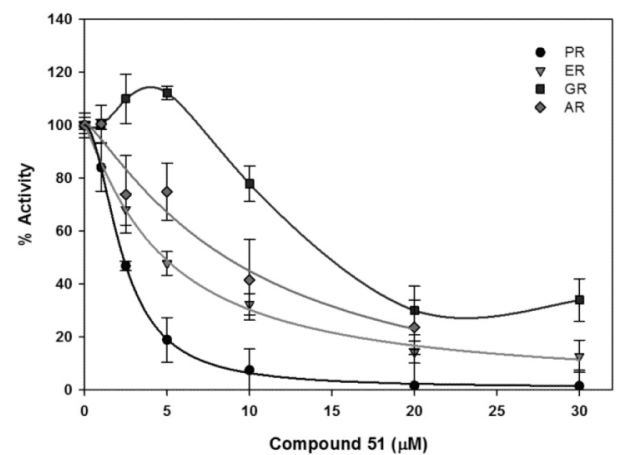

Figure 1.

Compound $\mathbf{5 1}$ is a selective inhibitor of PR-mediated transactivation. (A) Structure of $\mathbf{5 1 .}$ (B) Inhibition of transactivation by $\mathbf{5 1}$ in reporter gene assays. Reporter assays were performed as described in the Experimental section. For each hormone, activity in the absence of compound $\mathbf{5 1}$ was set as $\mathbf{1 0 0 \%}$. Error bars represent the SEM for at least three experiments. (C) $\mathrm{IC}_{50} \mathrm{~s}$ were calculated using Sigma Plot 11.0. 
(A)

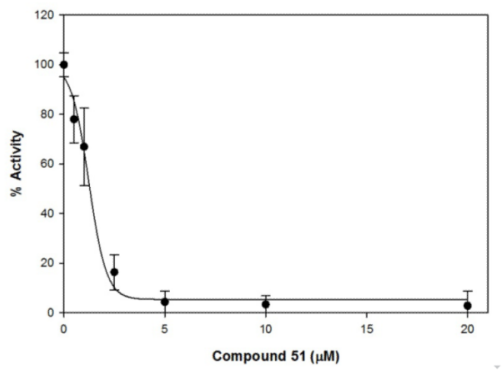

(B)

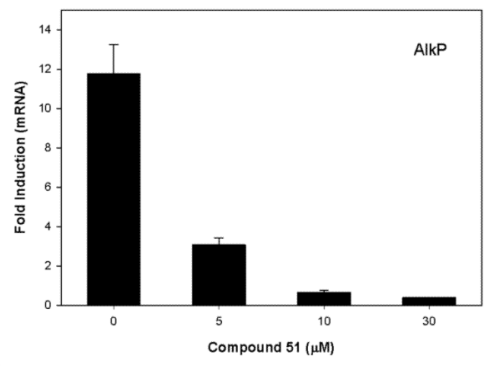

Figure 2.

Inhibition of progesterone-induced alkaline phosphatase enzyme activity (A) and mRNA levels (B) by compound $\mathbf{5 1}$ in T47D cells. Alkaline phosphatase assays and qRT-PCR were performed as described in the Experimental section. Error bars represent the SEM for at least three experiments. AlkP activity in the absence of $\mathbf{5 1}$ was set to $100 \%$. Enzyme activity $\mathrm{IC}_{50}=1.2 \mu \mathrm{M}$. AlkP mRNA in the absence of hormone and $\mathbf{5 1}$ was set to 1.0. 


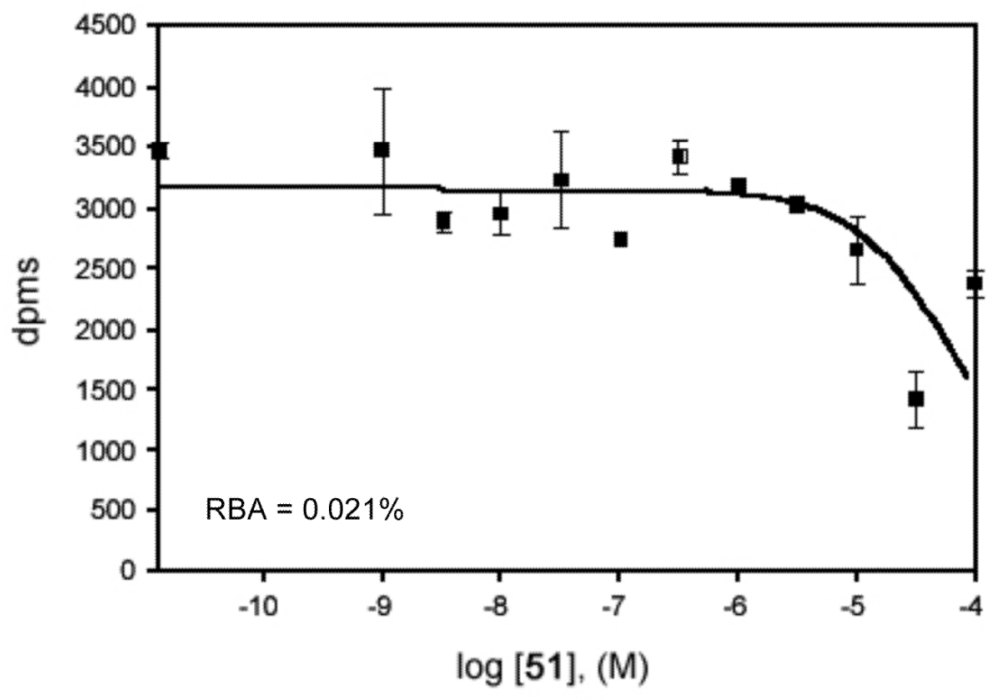

Figure 3.

Competitive binding of compound $\mathbf{5 1}$ with $10 \mathrm{nM}$ R5020 to the progesterone receptor. Competition assays were performed as described in the Experimental section. Error bars represent the SEM for at least three experiments. 


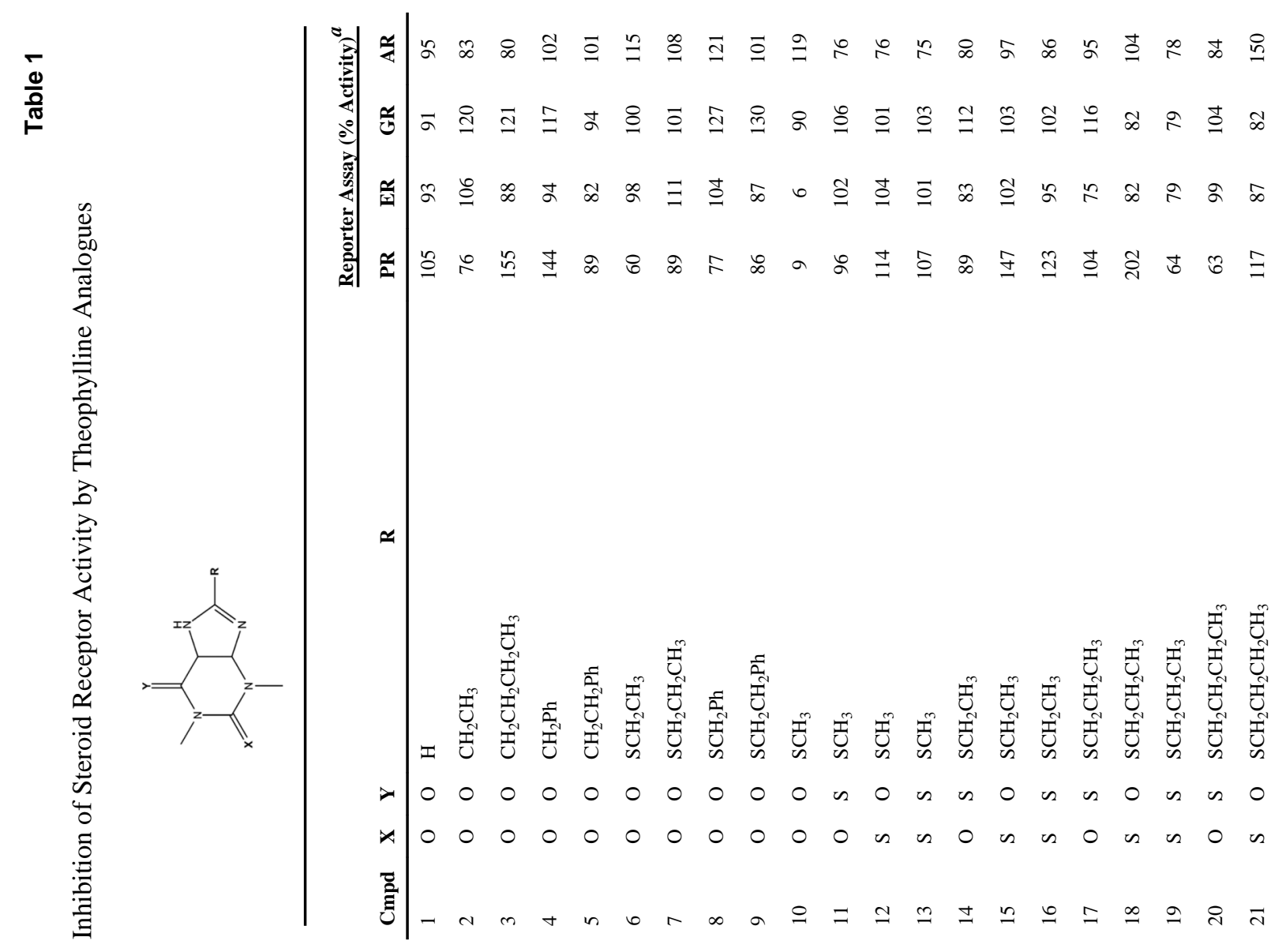

Steroids. Author manuscript; available in PMC 2013 May 01. 


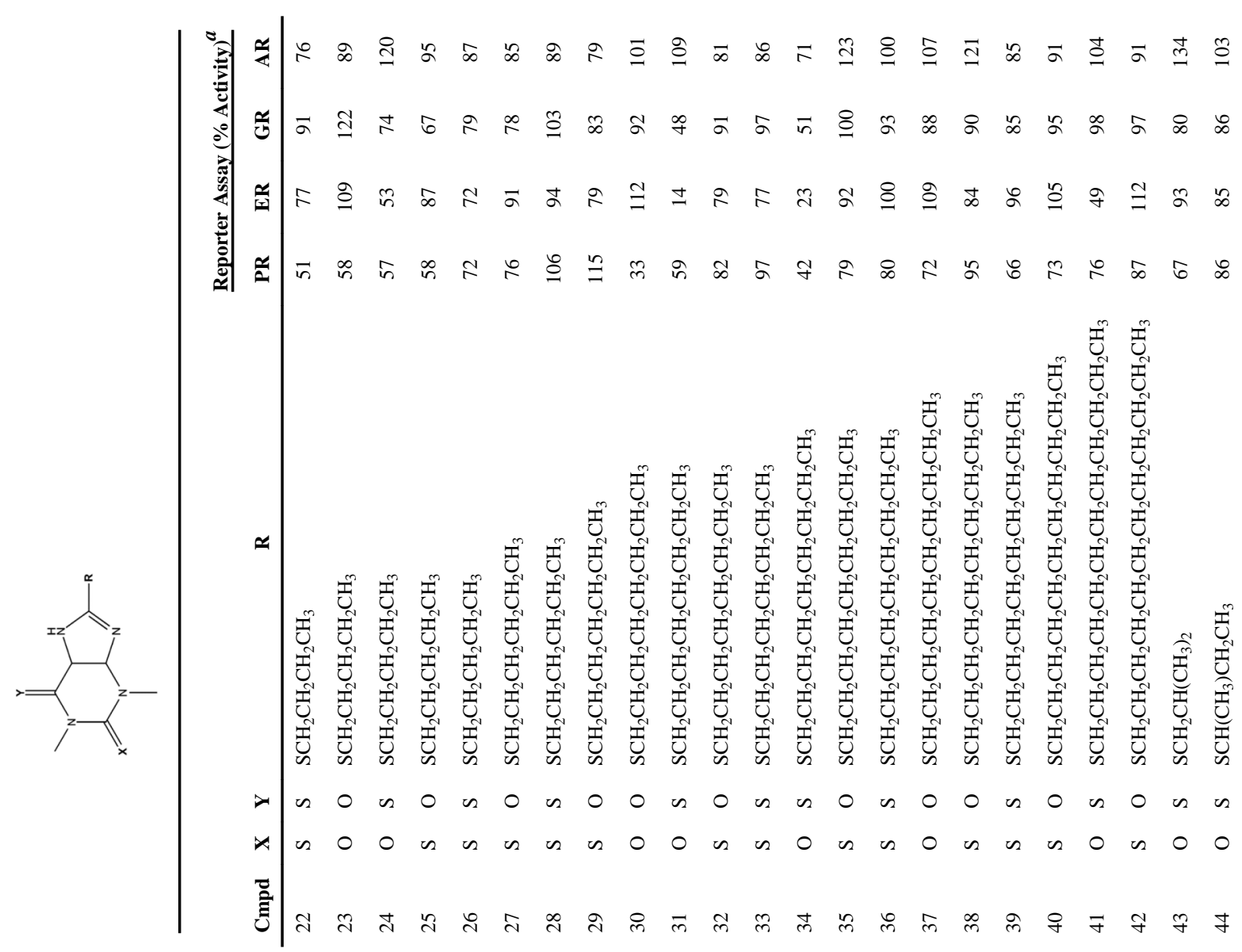




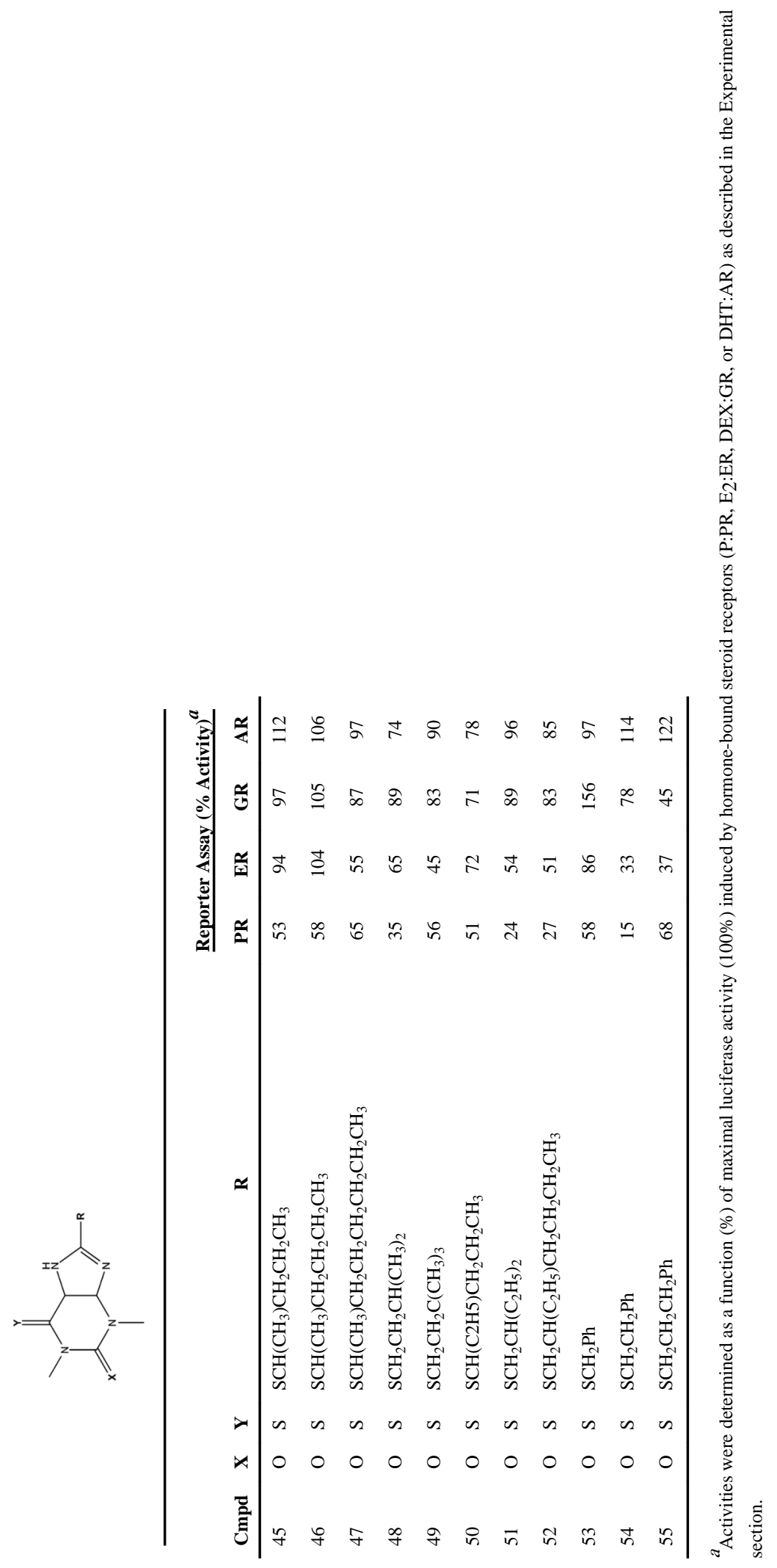

